\title{
POLITIK HUKUM PENGADOPSIAN RESTORATIVE JUSTICE DALAM PEMBAHARUAN HUKUM PIDANA
}

\author{
Septa Chandra \\ Fakultas Hukum Universitas Muhammadiyah Jakarta \\ Email : shev_tha1985@yahoo.com septa.candra85@gmail.com
}

\begin{abstract}
The purpose of this study was to find a political choice of law in criminal law reform. Using a juridical approach using secondary data, it can be concluded that the legal political reform criminal law in Indonesia is still ongoing and to be part of the development of the national legal system. Legal political development of the national legal system should be based on Pancasila as a guide and tool for political filtering of national law and UUDNRI 1945 Constitution as the basic law. One form of political reform criminal law is by adopting the concept of restorative justice as an alternative mechanism for the settlement of legal issues that occur without the use of judicial proceedings. With the approach of restorative justice, the enforcement of which has always used retributive approach (retaliation) would merely shift to restorative approaches (recovery). The concept of restorative justice can be political legal permanent (permanent) in building the national criminal justice system that will come.
\end{abstract}

Keywords: Politics Law, Restorative Justice and Criminal Case

\begin{abstract}
abstrak
Tujuan penelitian ini adalah untuk menemukan pilihan politik hukum dalam pembaharuan hukum pidana. Menggunakan pendekatan yuridis dengan menggunakan data sekunder dapat disimpulkan bahwa politik hukum pembaharuan hukum pidana di Indonesia saat ini masih terus berlangsung dan menjadi bagian dari pembangunan sistem hukum nasional. Politik hukum pembangunan sistem hukum nasional harus berdasarkan Pancasila sebagai pemandu dan alat filterisasi bagi politik hukum nasional dan UUD NRI Tahun 1945 sebagai hukum dasar. Salah satu bentuk politik pembaharuan hukum pidana adalah dengan mengadopsi konsep restorative justice sebagai alternatif mekanisme penyelesaian masalah hukum yang terjadi tanpa menggunakan proses peradilan. Dengan pendekatan restorative justice ini, penegakan hukum dari yang selama ini selalu menggunakan pendekatan retributif (pembalasan) semata-mata akan bergeser menjadi pendekatan restoratif (pemulihan). Konsep restorative justice dapat menjadi politik hukum yang bersifat tetap (permanen) dalam membangun sistem hukum pidana nasional yang akan datang.
\end{abstract}


Kata kunci : Politik Hukum, Restorative Justice, dan Perkara Pidana

\section{A. Pendahuluan}

Negara Indonesia adalah negara hukum (rechtsstaat), penegasan akan hal ini dapat dilihat dalam Pasal 1 ayat (3) Undang-Undang Dasar Negara Republik Indonesia Tahun 1945. Menurut Daniel S. Lev, penegasan yuridiskonstitusional oleh para founding fathers sebagaimana di atas sangatlah tepat, karena memang secara sosiologis berbagai golongan masyarakat Indonesia juga menopang/setuju negara hukum dengan berbagai alasan. ${ }^{1} \mathrm{Hal}$ ini mempunyai makna bahwa semua subsistem dari penyelenggaraan negara Indonesia dan sistem ketatanegaraannya, sistem tertib sosialnya harus diatur oleh hukum, dan juga semua elemen alat kekuasaan negara serta warga negara harus patuh pada hukum yang diciptakan untuk negara hukum Indonesia tersebut. Inilah juga disebut paham konstitusionalisme yang dianut dalam negara hukum. Oleh karena hukum menjadi sandaran pengaturan dan penjamin terjaganya ketertiban, maka segala strategi penyusunan hukum, penggunaan hukum, perlembagaan hukum, dan penegakan hukum menjadi suatu hal yang sangat penting guna mewujudkan cita negara hukum.

Untuk mewujudkan cita negara hukum sebagaimana di atas, maka harus dilakukan pembangunan berbagai bidang, diantaranya pembangunan di bidang hukum. Ketika membahas pembangunan di bidang hukum, tentunya tidak dapat melepaskan diri dari pembahasan tentang politik hukum (kebijakan hukum). Begitu juga sebaliknya, ketika berbicara mengenai politik hukum erat kaitannya dengan pembangunan hukum. Pada dasarnya pembangunan hukum merupakan tindakan atau kegiatan yang dimaksud untuk membentuk kehidupan hukum ke arah yang lebih baik dan kondusif. Pembangunan hukum bukan merupakan entitas yang berdiri sendiri, melainkan terintegrasi dengan pembangunan bidang lain, sehingga hal itu merupakan proses yang berkelanjutan dan bersinergi dengan bidang-bidang pembangunan lainnya. Tentunya di sini, pembangunan hukum tidak hanya dimaksudkan untuk pembangunan hukum positif, yaitu peraturan perundangundangan, tetapi juga dalam arti luas yang menunjuk pada sebuah sistem, yang tidak hanya meliputi pembangunan materi hukum, tetapi juga kelembagaan dan penegakan hukum, pelayanan hukum, dan peningkatan kesadaran hukum masyarakat dan aparatur hukum itu sendiri. ${ }^{2}$

\footnotetext{
${ }^{1}$ Daniel S. Lev, Hukum dan Politik di Indonesia: Keseimbangan dan Perubahan, Cetakan I, (Jakarta: LP3ES, 1990), hlm. 386

2 Chairul Huda, "Politik Hukum Pembangunan Sistem Hukum Nasional Dalam Konteks Pancasila, UUD NRI Tahun 1945, dan Global”, Makalah disampaikan pada Seminar Nasional Fakultas Hukum Universitas Muhammadiyah Jakarta, Tanggal 22 November 2014
} 
Filosofi yang dianut dalam pembangunan hukum nasional selama kurang lebih empat puluh tahun yaitu konsep hukum pembangunan yang menempatkan peranan hukum sebagai sarana pembaharuan masyarakat. Dalam konsep yang demikian, pelaksanaan pembangunan hukum mempunyai fungsi sebagai pemelihara dalam ketertiban dan keamanan, sebagai sarana pembangunan, sarana penegak keadilan, dan sarana pendidikan masyarakat. ${ }^{3}$ Oleh karena itu, apabila dalam pelaksanaan pembangunan, hukum diartikan sebagai sarana untuk mencapai tujuan negara, politik hukum nasional harus berpijak pada kerangka dasar, yaitu: ${ }^{4}$

1. politik hukum nasional harus selalu mengarah pada cita-cita bangsa, yaitu masyarakat adil dan makmur berdasarkan Pancasila;

2. politik hukum harus ditujukan untuk mencapai tujuan negara;

3. politik hukum harus dipandu oleh nilai-nilai Pancasila sebagai dasar negara, yaitu berbasis moral agama, menghargai dan melindungi hak asasi manusia tanpa diskriminasi, mempersatukan seluruh unsur bangsa, meletakkan kekuasaan di bawah kekuasaan rakyat, dan membangun keadilan sosial;

4. apabila dikaitkan dengan cita hukum negara Indonesia, politik hukum harus melindungi semua unsur bangsa demi integrasi atau keutuhan bangsa, mewujudkan keadilan sosial dalam ekonomi dan kemasyarakatan, mewujudkan demokrasi (kedaulatan rakyat) dan nomokrasi kedaulatan hukum, serta menciptakan toleransi hidup beragama berdasarkan keadaban dan kemanusiaan;

5. arah pembangunan hukum bukan sesuatu yang berdiri sendiri, melainkan terintegrasi dengan arah pembangunan di bidang lainnya memerlukan penyerasian. Betapapun arah pembangunan hukum bertitik tolak pada garis-garis besar gagasan dalam UUD NRI Tahun 1945, dibutuhkan penyelarasan dengan tingkat perkembangan masyarakat yang dimimpikan akan tercipta pada masa depan. Pembangunan hukum tidak identik dan tidak boleh diidentikkan dengan pembangunan undang-undang atau peraturan perundangan menurut istilah yang lazim digunakan di Indonesia. Membentuk undang-undang sebanyak-banyaknya, tidak berarti sama dengan membentuk hukum. Negara hukum bukan negara undang-undang. Pembentukan undang-undang hanya bermakna pembentukan norma hukum. Padahal tatanan sosial, ekonomi budaya, dan politik bukan tatanan normatif semata. Karena itulah maka diperlukan ruh tertentu agar tatanan tersebut memiliki kapasitas.

\footnotetext{
${ }^{3}$ Sunaryati Hartono, Hukum Ekonomi Pembangunan Indonesia, Bandung: Bina Cipta.

${ }^{4}$ Mahfud MD, Politik Hukum Menuju Pembangunan Sistem Hukum Nasional, Seminar Arah Pembangunan Hukum Menurut UUD 1945 Hasil Amandemen, BPHN, 2006. Dalam konteks ini politik hukum diartikan sebagai arah yang harus ditempuh dalam pembuatan dan penegakan hukum guna mencapai cita-cita dan tujuan negara.
} 
Sehubungan dengan hal-hal tersebut di atas, perubahan hukum yang dilaksanakan di Indonesia ini hendaknya diarahkan kepada penciptaan kondisi yang lebih mantap, sehingga setiap warga masyarakat dapat menikmati suasana serta iklim ketertiban dan kepastian hukum yang berintikan keadilan. Juga harus memberikan dukungan dan pengamanan kepada upaya pembangunan untuk mencapai kemakmuran, dengan cara mengadakan kodifikasi dan unifikasi hukum bidang-bidang tertentu dengan memperhatikan kesadaran hukum yang berkembang dalam masyarakat. Untuk itu perlu dilanjutkan langkah-langkah untuk menyusun perundangundangan yang menyangkut hak dan kewajiban asasi warga negara dalam rangka mengamalkan Pancasila dan UUD NRI Tahun 1945. Diharapkan seluruh warga negara Indonesia harus selalu sadar dan taat kepada hukum, sebaliknya kewajiban negara untuk menegakkan dan menjamin kepastian hukum. ${ }^{5}$

Sebelum membahas mengenai politik hukum pembaharuan hukum pidana, perlu disinggung dalam tulisan ini terlebih dahulu mengenai pengertian politik hukum menurut beberapa ahli hukum. Padma Wahyono memberikan pengertian politik hukum nasional adalah sebagai kebijaksanaan dasar yang menentukan arah, bentuk, maupun isi dari hukum yang akan dibentuk. Segi lain dari politik hukum adalah mengenai nilainilai, penentuan, pengembangan, dan pemberian bentuknya. ${ }^{6}$ Sedangkan Mahfud MD memberikan pengertian secara sederhana bahwa politik hukum sebagai kebijaksanaan hukum (legal policy) yang akan atau telah dilaksanakan secara nasional oleh pemerintah. ${ }^{7}$ Sementara itu, Sudarto berpandangan politik hukum atau kebijakan hukum adalah usaha untuk mewujudkan peraturan-peraturan yang baik sesuai dengan keadaan dan situasi pada suatu saat. ${ }^{8}$ Pada kesempatan lain beliau mendefinisikan politik hukum sebagai kebijakan dari badan-badan yang berwenang untuk menetapkan peraturan-peraturan yang dikehendaki yang diperkirakan bisa digunakan untuk mengekspresikan apa yang terkandung dalam masyarakat dan mencapai apa yang dicita-citakan.

Sementara itu, Bagir Manan mengatakan bahwa politik hukum tidak terlepas dari kebijaksanaan bidang lain. Penyusunan politik hukum, harus diusahakan selalu seiring dengan aspek-aspek kebijaksanaan di bidang

\footnotetext{
${ }^{5}$ Abdul Manan, Aspek-Aspek Pengubah Hukum, (Jakarta: Kencana Prenada Media, 2009), hlm. 5

${ }^{6}$ Padmo Wahyono, Indonesia Negara Berdasarkan Atas Hukum, (Jakarta: Ghalia Indonesia, 1986), hlm. 160

${ }^{7}$ Moh. Mahfud MD, Politik Hukum di Indonesia, (Jakarta: Pustaka LP3ES Indonesia, 1998), hlm. 7-9

${ }^{8}$ Sudarto, Hukum dan Hukum Pidana, (Bandung: Alumni, 1981), hlm. 159

${ }^{9}$ Sudarto, Hukum Pidana dan Perkembangan Masyarakat, (Bandung: Sinar Baru, 1983), hlm. 20
} 
lainnya, seperti bidang ekonomi, bidang politik, bidang sosial, dan sebagainya. Namun demikian, setidak-tidaknya ada dua lingkup utama politik hukum, yaitu sebagai berikut:

1. politik pembentukan hukum yaitu kebijaksanaan yang bersangkutan dengan penciptaan, pembaharuan, dan pengembangan hukum. Politik pembentukan hukum mencakup hal-hal sebagai berikut:

a. kebijaksanaan (pembentukan) perundang-undangan;

b. kebijaksanaan (pembentukan) hukum yurisprudensi atau keputusan hakim;

c. kebijaksanaan terhadap peraturan tidak tertulis lainnya.

2. politik pelaksanaan hukum yaitu kebijaksanaan yang berhubungan dengan hal-hal sebagai berikut ${ }^{10}$

a. kebijaksanaan di bidang peradilan; dan

b. kebijaksanaan di bidang pelayanan hukum Abdul Hakim Garuda Nusantara mengartikan politik hukum secara harfiah sebagai kebijakan hukum (legal policy) yang hendak diterapkan atau dilaksanakan secara nasional oleh suatu pemerintah negara tertentu. Lebih lanjut Gurada Nusantara mengatakan politik hukum nasional bisa meliputi ${ }^{11}$ :

1) pelaksanaan ketentuan hukum yang telah ada secara konsisten;

2) pembangunan hukum yang intinya adalah pembaharuan terhadap ketentuan hukum yang telah ada dan yang dianggap usang, dan penciptaan ketentuan hukum baru yang diperlukan untuk memenuhi tuntutan perkembangan yang terjadi dalam masyarakat;

3) penegasan fungsi lembaga penegak atau pelaksana hukum dan pembinaan anggota;

4) meningkatkan kesadaran hukum masyarakat menurut persepsi kelompok elit pengambil kebijakan.

Kemudian, Syofrin Syofyan dan Asyhar Hidayat melihat politik hukum dalam konteks hukum nasional mengatakan bahwa politik hukum nasional adalah pernyataan kehendak negara melalui pembentuk undangundang (legislatif), melakukan kebijakan hukum untuk membentuk suatu pilihan hukum dan dikembangkan sesuai dengan tujuan negara berdasarkan kebijakan yang akan atau telah dilaksanakan oleh pemerintah. ${ }^{12}$ Dari

10 Bagir Manan, Politik Hukum Otonomi Sepanjang Peraturan Perundang-undangan Pemerintahan Daerah. Dalam Martin H. Hutabarat, et. All (Penyunting), Hukum dan Politik Indonesia: Tinjauan Analitis Dekrit Presiden dan Otonomi Daerah, (Jakarta: Sinar Harapan, 1996), hlm. 145

11 Abdul Hakim Garuda Nusantara, "Politik Hukum Nasional", makalah disampaikan pada Karya Latihan Bantuan Hukum (Kalabahu), diselenggarakan Yayasan LBH Indonesia dan LBH Surabaya, September 1985.

12 Syofrin Sofyan dan Asyhar Hidayat, Hukum Pajak dan Permasalahannya, (Bandung: Refika Aditama, 2003), hlm. 4-5 
berbagai pendapat para ahli hukum tersebut, secara substansi pada dasarnya sama. Walaupun sepintas masing-masing para ahli hukum tersebut memberi pengertian yang berbeda-beda. Dalam konteks negara Indonesia, sebenarnya politik hukum yang dicita-citakan tersebut telah dirumuskan dalam Pancasila dan pembukaan UUD NRI Tahun 1945.

Pancasila yang merupakan sumber segala sumber hukum Indonesia dan UUD NRI Tahun 1945 sebagai hukum dasar, menjadi pedoman, batu uji, pemandu, dan alat filterisasi sekaligus menjadi tujuan dari semua politik hukum nasional. Sunaryati Hartono mengatakan bahwa apabila kita menempatkan hukum sebagai jembatan yang akan membawa kita kepada ide yang dicita-citakan, maka terlebih dahulu kita harus mengetahui masyarakat yang bagaimana yang dicita-citakan oleh rakyat Indonesia. Setelah kita mengetahui bagaimana bentuk masyarakat yang dicita-citakan oleh rakyat Indonesia, dapatlah dicari sistem hukum yang bagaimana yang dapat mewujudkan cita-cita dimaksud, dan politik hukum yang bagaimana dapat menciptakan sistem hukum yang dikehendaki. ${ }^{13}$

Berhubungan dengan bentuk masyarakat yang dicita-citakan oleh rakyat Indonesia, menurut Sunaryati Hartono adalah suatu masyarakat yang adil dan makmur secara merata yang dicapai dengan cara yang wajar dan berperikemanusiaan, yang pada gilirannya tercapai keselarasan, keserasian, dan ketentraman di seluruh negeri. ${ }^{14}$ Sementara itu, terkait dengan sistem hukum nasional yang dapat mewujudkan masyarakat yang dicita-citakan oleh rakyat Indonesia dimaksud, menurut Sunaryati Hartono adalah sistem hukum nasional yang berdasarkan Pancasila dan UUD NRI Tahun 1945. ${ }^{15}$ Sementara itu, Romli Atmasasmita mengatakan bahwa hakikat dari politik hukum nasional adalah kepastian hukum, keadilan, dan kemanfaatan, harus dilihat sebagai conditio sine qua non, bukan sebaliknya sebagai condition qum qua non. ${ }^{16}$

Lebih lanjut, Romli Atmasasmita mengemukakan pendapatnya sebagai berikut:

"Hukum Nasional (Indonesia) sebagai suatu sistem belum terbentuk secara holistik, komprehensif, ataupun belum diperkaya nilai-nilai kehidupan masyarakat adat untuk beradaptasi dengan kehidupan masyarakat maju. Usaha untuk menyatakan telah

\footnotetext{
${ }^{13}$ Lihat Sunaryati Hartono, Perspektif Politik Hukum Nasional, Dalam Artidjo Alkostar dan M. Sholeh Amin (Ed), Pembangunan Hukum Dalam Perspektif Politik Hukum Nasional, (Jakarta: Rajawali, 1986), hlm. 1

${ }^{14}$ Ibid.,

15 Sunaryati Hartono, Politik Hukum Nasional Menuju Satu Sistem Hukum Nasional, (Bandung: Alumni, 1991), hlm. 58-66

16 Romli Atmasasmita, Teori Hukum Integratif: Rekonstruksi Terhadap Teori Hukum Pembangunan dan Teori Hukum Progresif, (Yogyakarta: Genta Publishing, 2012), hlm. 111
} 
terdapat suatu sistem hukum nasional, terbukti hanya merupakan pewarisan sistem hukum pewarisan Hindia Belanda yang menganut "Civil Law System" semata-mata yang dipaksakan berlakunya ditengah-tengah masyarakat hukum adat. Perubahan terhadap KUHP pada masa pasca kemerdekaan Republik Indonesia dan setelah era reformasi, antara lain dilakukan dengan memasukan ketentuan mengenai pembajakan udara dan larangan ideologi marxisme-komunisme. Pembentukan sistem hukum nasional sampai saat ini masih belum selesai dan patut dipertanyakan sebelum dan setelah Indonesia memasuki era reformasi, pembentukan tersebut lebih banyak hasil harmonisasi pengaruh hukum asing atau hukum Internasional ke dalam peraturan perundang-undangan". ${ }^{17}$

Berdasarkan pemaparan Romli Atmasasmita tersebut, maka politik hukum pembaharuan hukum pidana merupakan sistem yang sedang terus dibangun, atau dapat dikatakan bahwa sistem hukum pidana nasional Indonesia merupakan sistem yang masih dicita-citakan (Ius Constituendum). Berdasarkan hal tersebut, menjadi suatu keharusan secara konseptual dan mendasar dilaksanakan transformasi hukum barat, hukum Islam, dan hukum adat ke dalam sistem nasional, sehingga menjadi satu kesatuan yang utuh sebagai satu kesatuan sistem hukum nasional yang berfilsafatkan Pancasila dan UUD NRI Tahun 1945.

Adapun karakteristik dari sistem hukum nasional nantinya, tergantung dari politik hukum nasional Indonesia. Dengan perkataan lain, bahwa politik hukum nasional Indonesia akan menentukan karakteristik dari sistem hukum nasional Indonesia. Jadi terciptanya sistem hukum nasional yang berfilsafatkan Pancasila dan berdasarkan UUD NRI Tahun 1945, tergantung dari politik hukum nasional. ${ }^{18}$ Sistem hukum nasional yang berdasarkan Pancasila dan UUD NRI Tahun 1945, yang akan diwujudkan melalui politik hukum nasional, merupakan sistem hukum yang bersumber dan berakar pada berbagai sistem hukum yang digunakan oleh masyarakat Indonesia, yang meliputi sistem hukum Adat, sistem hukum Islam, dan sistem hukum Eropa. Artinya, dalam pembentukan sistem hukum nasional yang holistik dan komprehensif harus menjadikan sistem hukum Adat, sistem hukum Islam, dan sistem hukum Eropa sebagai bahan bakunya.

Berdasarkan elaborasi ragam definisi politik hukum di atas, penulis menyimpulkan bahwa politik hukum adalah kebijakan dasar penyelenggara negara dalam bidang hukum yang akan, sedang, dan telah berlaku, yang bersumber dari nilai-nilai yang berlaku di masyarakat untuk mencapai tujuan

\footnotetext{
${ }^{17}$ Ibid., hlm. 60-61

${ }^{18}$ Otong Rosadi dan Andi Desmon, Studi Politik Hukum: Suatu Optik Ilmu Hukum, Edisi II, (Yogyakarta: Thafa media, 2013), hlm. 45
} 
negara yang dicita-citakan. Kata kebijakan di sini berkaitan dengan adanya strategi yang sistematis, terinci, dan mendasar. Dalam merumuskan dan menetapkan hukum yang telah dan akan dilakukan, politik hukum menyerahkan otoritas legislasi kepada penyelenggara negara, tetapi dengan tetap memperhatikan nilai-nilai yang berlaku di masyarakat. Kesemuanya itu diarahkan dalam rangka mencapai tujuan negara yang dicita-citakan.

Menurut Teuku Mohammad Radhie, mengatakan bahwa pembaharuan hukum yang dilaksanakan di Indonesia hendaknya harus berada dalam bingkai pembinaan hukum nasional. Yang dimaksud dengan pembinaan hukum nasional disini adalah merupakan usaha-usaha kodifikasi di segala bidang hukum, yakni hukum perdata, hukum pidana, hukum acara, dan hukum lainnya jika diperlukan. Termasuk juga dalam pengertian pembinaan hukum nasional adalah usaha pembaharuan hukum secara sektoral di berbagai bidang hukum yang mendesak. Ruang lingkup pembinaan hukum nasional termasuk juga instansi penegak hukum dan prosedurnya. Jadi pembaharuan hukum itu bersifat komprehensif dalam rangka menuju pembentukan sistem hukum nasional sebagai jati diri bangsa Indonesia. Usaha ini dapat berhasil kalau ada hubungan dan dukungan dari semua pihak terkait dalam usaha membangun hukum nasional yang mencerminkan jiwa bangsa Indonesia sendiri. ${ }^{19}$

Berbicara mengenai pembaharuan hukum sangat erat hubungannya dengan kebijakan hukum (legal policy). Hoefnagels mengatakan kebijakan hukum merupakan bagian tidak terpisahkan (integral) dari kebijakan sosial (social policy); atau dengan kata lain, kebijakan sosial mencakup di dalamnya kebijakan hukum, yang selengkapnya dikatakan kebijakan penegakan hukum (law enforcement policy). ${ }^{20}$ Jadi, kebijakan perundangundangan (legislative policy) dan kebijakan penegakan hukum (law enforcement policy) merupakan bagian dari kebijakan sosial (social policy), ${ }^{21}$ yang menurut Barda Nawawi Arief adalah kebijakan atau upaya untuk mencapai kesejahteraan sosial. ${ }^{22}$ Lebih lanjut Barda Nawawi Arief mengatakan kebijakan sosial merupakan segala usaha yang rasional untuk mencapai kesejahteraan masyarakat dan sekaligus mencakup perlindungan masyarakat. Jadi, dalam pengertian 'social policy' sekaligus tercakup di dalamnya 'social walfare policy' dan 'social defence policy'.

\footnotetext{
19 Teuku Muhammad Radhie, Beberapa Pemikiran Pembangunan Hukum di Indonesia, (Bandung: Alumni, 1980), hlm. 9

${ }^{20}$ G.P. Hoefnagels, The Other side of Criminology, (Holland: Deventer-Kluwer, 1978), hlm. 57

${ }^{21}$ Ibid.,

${ }^{22}$ Barda Nawawi Arief, Bunga Rampai Kebijakan Hukum Pidana, (Bandung: Citra Aditya Bakti, 1996), hlm. 3

${ }^{23}$ Ibid.,
} 
Kebijakan untuk membuat hukum pidana yang baik dan berdaya guna atau politik hukum pidana (penal policy) merupakan bagian dari politik kriminal (criminal policy) sebagaimana telah diuraikan sebelumnya. Marc Ancel mengatakan bahwa:

"Kebijakan hukum pidana adalah "suatu ilmu sekaligus seni yang pada akhirnya mempunyai tujuan praktis untuk memungkinkan peraturan hukum positif dirumuskan secara lebih baik dan untuk memberi pedoman tidak hanya kepada pembuat undang-undang, tetapi juga kepada pengadilan yang menerapkan undang-undang, tetapi juga kepada pengadilan yang menerapkan undang-undang dan juga kepada para penyelenggara negara atau pelaksana putusan pengadilan".

Lebih lanjut dikatakan:

"Di antara studi mengenai faktor-faktor kriminologis di satu pihak dan studi mengenai teknik perundang-undangan di lain pihak, ada tempat bagi suatu ilmu pengetahuan yang mengamati dan menyelidiki fenomena legislatif dan bagi suatu seni yang rasional, dimana para sarjana dan praktisi, para ahli kriminologi dan sarjana hukum dapat berkerja sama tidak sebagai pihak yang saling berlawanan atau saling berselisih, tetapi sebagai kawan sekerja yang terikat dalam tugas bersama, yaitu terutama untuk menghasilkan suatu kebijakan pidana yang realistik, humanis, dan berpikiran maju (progresif) lagi sehat". ${ }^{24}$

Sejalan dengan pendapat di atas, Sudarto mengatakan bahwa, melaksanakan politik hukum pidana berarti mengadakan pemilihan hukum untuk mencapai hasil perundang-undangan pidana yang paling baik, dalam arti memenuhi syarat keadilan dan dayaguna. Pada kesempatan lain beliau mengatakan bahwa melaksanakan politik hukum pidana berarti, usaha mewujudkan peraturan perundang-undangan pidana sesuai dengan keadaan dan situasi pada suatu waktu dan untuk masa yang akan datang. ${ }^{25}$ Sedangkan Murder yang menggunakan istilah "strafrechtspolitiek", mendefinisikannya sebagai garis kebijakan untuk menentukan ${ }^{26}$ :

1. seberapa jauh ketentuan-ketentuan pidana yang berlaku perlu diubah atau diperbaharui;

2. apa yang dapat diperbuat untuk mencegah terjadinya tindak pidana; dan

3. cara bagaimana penyelidikan, penuntutan, peradilan, dan pelaksanaan pidana harus dilaksanakan.

Dengan demikian, dalam pembaharuan hukum pidana (termasuk hukum pidana formil), harus ditempuh dengan pendekatan yang berorientasi

\footnotetext{
${ }^{24}$ Ibid., hlm. 4

${ }^{25}$ Ibid., hlm. 27-28

${ }^{26}$ Ibid., hlm. 28
} 
pada kebijakan (policy-oriented approach), karena memang pada hakikatnya ia hanya merupakan bagian dari suatu langkah kebijakan hukum (policy), yaitu bagian dari politik hukum/penegakan hukum, politik hukum pidana, politik kriminal, dan politik sosial, dan sekaligus pendekatan yang berorientasi pada nilai (value-oriented approach), karena dalam setiap kebijakan terkandung pula pertimbangan nilai. Pembaharuan hukum pidana pada hakikatnya mengandung makna, suatu upaya untuk melaksanakan reorientasi dan reformasi hukum pidana yang sesuai dengan nilai-nilai sentral sosio-politik, sosio-filosofik, dan sosio-kultural masyarakat Indonesia yang melandasi kebijakan sosial, kebijakan kriminal, dan kebijakan penegakan hukum di Indonesia. ${ }^{27}$

Terkait dengan politik hukum pembaharuan hukum pidana dalam hukum pidana nasional yang akan datang dikenal adanya konsep restorative justice. Konsep ini tergolong baru dalam proses penegakan hukum pidana dan juga mempertanggungjawabkan pelakunya. Dalam konsep ini menawarkan bentuk penyelesaian berbagai kasus hukum yang terjadi di luar proses peradilan pidana yang sudah, agar masyarakat tidak hanya tergantung pada prosedur yang ada saat ini. Namun tetap mendapatkan keadilan dan penyelesaian masalah terutama untuk korban sebagai pihak yang paling dirugikan (menderita), di samping juga untuk pertanggungjawaban pelaku. Salah satu bentuk solusi yang ditawarkan adalah proses penyelesaian dalam konteks restorative justice (keadilan restoratif).

Konsep pendekatan restorative justice merupakan suatu pendekatan yang lebih menitikberatkan pada kondisi terciptanya keadilan dan keseimbangan bagi pelaku tindak pidana serta korbannya sendiri. Mekanisme tata acara dan peradilan pidana yang berfokus pada pemidanaan diubah menjadi proses dialog dan mediasi untuk menciptakan kesepakatan atas penyelesaian perkara pidana yang lebih adil dan seimbang bagi pihak korban dan pelaku. Restorative justice itu sendiri memiliki makna keadilan yang merestorasi, adapun restorasi disini memiliki makna yang lebih luas dari apa yang dikenal dalam proses peradilan pidana konvensional adanya restitusi atau ganti rugi terhadap korban.

Hal ini berangkat dari pandangan bahwa dalam suatu peristiwa kejahatan, penderitaan orang yang telah menjadi korban tidak saja berakibat pada orang itu sendiri, tetapi juga berdampak pada orang-orang di sekitarnya. Bahkan juga berdampak pada masyarakat dan negara dalam lingkup yang lebih luas. Dalam praktek peradilan pidana, korban hanya diperlakukan atau diposisikan sebagai saksi (korban), tanpa berhak untuk ikut serta berperan aktif dalam sidang pengadilan. Aparat penegak hukum hanya mendudukkan korban sebagai instrumen dalam rangka membantu

${ }^{27}$ Ibid., hlm. 31 
mereka untuk menghukum atau menjatuhkan pidana bagi pelaku, tanpa pernah berlanjut pada apa yang dapat mereka berikan untuk kepentingan korban.

Namun demikian, dalam konsep restorative justice meliputi pemulihan hubungan antara pihak korban dan pelaku. Pemulihan hubungan ini bisa didasarkan atas kesepakatan bersama antara korban dan pelaku. Pihak korban dapat menyampaikan mengenai kerugian yang dideritanya dan pelaku pun diberi kesempatan untuk menebusnya, melalui mekanisme ganti rugi, perdamaian, kerja sosial, maupun kesepakatan-kesepakatan lainnya. Hal ini menjadi penting, karena proses pemidanaan konvensional tidak memberikan ruang kepada pihak yang terlibat, dalam hal ini korban dan pelaku untuk berpartisipasi aktif dalam penyelesaian masalah mereka.

Pada akhir-akhir ini terlihat seolah-olah hanya pengadilan tempat yang paling baik untuk menyelesaikan masalah (konflik) hukum dan mencari keadilan. Sehingga, setiap indikasi adanya tindak pidana, tanpa memperhitungkan eskalasi perbuatannya, akan terus digulirkan ke ranah penegakan hukum yang hanya menjadi yurisdiksi para penegak hukum. Partisipasi aktif dari masyarakat seakan tidak menjadi penting lagi, semuanya hanya bermuara pada putusan pengadilan dalam bentuk pemidanaan (punishment) tanpa melihat esensinya. Padahal, dalam suatu peradilan pidana pihak-pihak yang berperan adalah penuntut umum, hakim, terdakwa, dan penasehat hukum serta saksi-saksi. Pihak korban diwakili oleh penuntut umum dan untuk menguatkan pembuktian lazimnya yang bersangkutan dijadikan saksi (korban). ${ }^{28}$ Namun belumlah memberikan dampak atau manfaat yang nyata bagi korban kejahatan.

Padahal di banyak negara sudah mulai memikirkan alternatif lain untuk menyelesaikan konflik yang ada dalam masyarakat. Hal ini disebabkan karena ketidakpuasan dan frustasi terhadap penerapan hukum pidana yang ada selama ini, serta penerapan sistem peradilan pidana (Criminal Justice System) yang tidak memberikan keadilan bagi individu, perlindungan kepada korban, dan tidak memberikan manfaat kepada masyarakat. Apabila dilihat dari sejarahnya, pendekatan model restorative justice sebenarnya merupakan pendekatan darurat pada era 1960 dalam rangka menyelesaikan kasus-kasus pidana, yang tidak menggunakan sistem peradilan pidana. Dengan pendekatan restorative justice ini, pendekatan ini fokus pada partisipasi secara langsung dari pelaku, korban, dan masyarakat dalam proses penyelesaian kasus-kasus pidana. Memang pendekatan ini dalam praktek masih mengalami perdebatan secara teori, namun pandangan ini berkembang dan mempunyai dampak terhadap kebijakan hukum (legal

\footnotetext{
${ }^{28}$ Bambang Waluyo, Viktimologi Perlindungan Saksi dan Korban, (Jakarta: Sinar Grafika, 2011), hlm. 8
} 
policy) dan praktek penegakan hukum di beberapa negara. Restorative justice dianggap sebagai bentuk pemikiran baru yang dapat digunakan untuk merespon berbagai kejahatan dan menjawab ketidakpuasan dari kinerja sistem peradilan pidana pada saat ini.

Selain itu, konsep restorative justice juga dianggap sesuai dengan nilai-nilai Pancasila yang merupakan sumber segala sumber hukum Indonesia serta merupakan sistem hukum yang bersumber dan berakar pada berbagai sistem hukum yang digunakan oleh masyarakat Indonesia, yang meliputi sistem hukum Adat, dan sistem hukum Islam yang mengutamakan musyawarah dalam penyelesaian masalah (konflik) yang terjadi antar sesama anggota masyarakat. Satjipto Rahardjo mengatakan, penegakan hukum mengatur suatu usaha untuk mewujudkan ide-ide dan konsep-konsep menjadi kenyataan. Penegakan hukum adalah suatu proses mewujudkan keinginan-keinginan hukum menjadi kenyataan. Yang disebut dengan keinginan-keinginan hukum di sini tidak lain adalah pikiran-pikiran badan pembuat undang-undang yang dirumuskan dalam peraturan-peraturan hukum itu. Pembicaraan mengenai proses penegakan hukum ini menjangkau pula sampai kepada pembuat hukum. Perumusan pikiran-pikiran pembuat undang-undang (hukum) yang dituangkan dalam peraturan hukum akan turut menentukan bagaimana penegakan hukum itu dijalankan. ${ }^{29}$ Jadi, tidak bisa dipisahkan begitu saja penegakan hukum dan pembuatan hukum.

Upaya penegakan hukum memberikan arti adanya upaya untuk menjaga agar keberadaan hukum yang diakui di dalam suatu masyarakat dapat tetap ditegakkan. Upaya tersebut pada dasarnya harus menjamin agar setiap warga negara mematuhi hukum yang berlaku di dalam masyarakat yang bersangkutan. Menurut Rudi Hartono, sejalan dengan asas restitution in integurm, ${ }^{30}$ bahwa keseimbangan dalam masyarakat yang telah terganggu (karena tidak dilaksanakan atau dilanggarnya suatu aturan hukum) harus dipulihkan ke keadaan semula, untuk tujuan menciptakan suasana yang teratur, tertib, damai, dan aman, yang merupakan jaminan bagi kelangsungan hidup manusia. Hukum mengatur dan menguasai manusia dalam kehidupan bersama, maka tata hukum bertitik tolak pada penghormatan dan perlindungan manusia. Oleh karena itu, agar perlindungan manusia (justiabelen) terlindungi, sesuai dengan adagium "fiat justitia et pereat mundus", hukum harus ditegakkan walaupun langit runtuh, baik dalam keadaan normal atau damai, atau pada saat terjadi pelanggaran hukum.

\footnotetext{
${ }^{29}$ Satjipto Rahardjo, Masalah Penegakan Hukum Suatu Tinjauan Sosiologis, (Jakarta: Badan Pembinaan Hukum Nasional Departemen Kehakiman, 1993), hlm. 116

${ }^{30}$ Rudi Hartono, Kewenangan Kepolisian Menurut KUHAP Dalam Perspektif HAM, makalah Semiloka: KUHAP dan Menuju Fair Trial "Victim Protection". LBH Yogyakarta, 24 Juli 2013, hlm. 1
} 
Akan tetapi harus diingat, bahwa dalam penegakan hukum, haruslah disesuaikan dengan cita hukum bangsa yang bersangkutan. Artinya, penegakan hukum tersebut haruslah sesuai dengan falsafah Pancasila, pandangan hidup, kaidah, dan prinsip yang dianut oleh masyarakat yang bersangkutan, sehingga akan sesuai dengan kesadaran hukum yang mereka miliki. Untuk itu, penegakan hukum haruslah sesuai dengan nilai-nilai yang hidup dan dijunjung tinggi oleh masyarakat, yaitu nilai-nilai Pancasila, nilainilai tersebut antara lain: ketuhanan, keadilan, kepatutan, keselarasan (harmoni), persatuan, perdamaian, kemanusiaan (humanisme), ketertiban, kepatutan, dan kekeluargaan (gotong royong). Tentunya, sebagai sebagai negara yang menganut sistem Eropa Kontinental, ${ }^{31}$ sedapat mungkin nilainilai dinyatakan dalam bentuk undang-undang, termasuk dalam hal nilai dan kaidah penegakan hukum.

Dengan konsep restorative justice ini fenomena dalam penegak hukum di Indonesia yang selama ini dianggap telah merusak keadilan masyarakat dan dianggap jauh dari nilai-nilai Pancasila tidak perlu terjadi lagi. Misalnya, selama ini kita menyaksikan berbagai kasus hukum yang terjadi mulai dari seorang nenek yang mencuri mangkok, seorang nenek yang mencuri satu buah semangka, seorang anak yang mencuri sandal jepit, seorang anak yang menuntut ibu kandungnya, dan berbagai masalah hukum lainnya yang sebenarnya sepele dan ringan ataupun perbuatan-perbuatan yang dikategorikan sebagai tindak pidana yang sebenarnya juga dapat diselesaikan dengan konsep restorative justice tersebut. Penyelesaian konflik dengan menggunakan konsep ini dipandang sebagai bentuk penyelesaian yang bernilaikan Pancasila, terutama sila ke-4 (musyawarah), namun tetap tidak melupakan kepentingan korban serta nilai keadilan dan kemanfaatan bagi para pihak yang sedang berkonflik. Dari uraian tersebut muncul sebuah pertanyaan, yakni bagaimanakah politik hukum pembaharuan hukum pidana terhadap konsep restorative justice sebagai bentuk pendekatan baru dalam hukum pidana nasional yang akan datang.

\section{B. Pembahasan}

\section{Konsep Restorative Justice}

Penegakan hukum bukanlah merupakan suatu kegiatan yang berdiri sendiri, melainkan mempunyai hubungan timbal balik yang erat dengan masyarakatnya. Oleh karena itu, dalam membicarakan masalah ini sebaiknya tidak mengabaikan pembicaraan mengenai struktur masyarakat yang ada dibelakangnya. Penegakan hukum dalam suatu masyarakat mempunyai kecenderungan-kecenderungannya sendiri yang disebabkan oleh struktur masyarakatnya. Struktur masyarakat ini memberikan pengaruh, baik berupa

\footnotetext{
${ }^{31}$ Munir Fuady, Aliran Hukum Kritis, Paradigma Ketidakberdayaan Hukum, (Bandung: Citra Aditya Bakti, 2003), hlm. 58-59
} 
penyediaan sarana sosial yang memungkinkan penegakan hukum itu dijalankan, maupun memberikan hambatan-hambatan yang menyebabkan ia tidak dapat dijalankan atau kurang dapat dijalankan secara optimal. ${ }^{32}$

Munculnya konsep restorative justice merupakan salah satu bentuk penegakan hukum yang sesuai dengan kesadaran hukum yang mereka miliki atau sesuai dengan nilai-nilai yang ada dan dijunjung tinggi oleh masyarakatnya. Sebab, ketika penegakan hukum dilakukan, pada dasarnya masyarakat mengharapkan adanya kepastian hukum, karena dengan adanya kepastian hukum masyarakat akan lebih tertib, merupakan perlindungan secara yustisiabel terhadap tindakan sewenang-wenang yang sehingga seseorang akan mendapatkan sesuatu dalam keadaan tertentu. Sebaliknya masyarakat mengharapkan adanya manfaat dalam pelaksanaan dan penegakan hukum, maka jangan sampai justru karena pelaksanaan atau penegakan hukum justru menimbulkan keresahan dalam masyarakat. Masyarakat juga sangat berkepentingan bahwa dalam pelaksanaan atau penegakan hukum memperhatikan unsur keadilan, walaupun hukum tidak identik dengan keadilan, karena hukum bersifat umum yang mengikat setiap orang atau bersifat menyamaratakan, sedangkan keadilan bersifat subjektif, individualistik, dan tidak menyamaratakan.

Kembali kepada konsep Restorative Justice, sebenarnya telah muncul cukup lama, kurang lebih dari dua puluh tahun yang lalu sebagai alternatif penyelesaian perkara pidana, khususnya anak, dengan berbagai pertimbangannya. Sebagaimana dikemukakan oleh John Braithwaite bahwa, restorative justice sebuah arah baru antara "justice" dan "walfare model", kemudian antara "retribution" dan "rehabilitation". ${ }^{33}$ Di Amerika Utara, Australia, dan sebagian Eropa, keadilan restoratif sudah diterapkan pada semua tahap proses peradilan pidana konvensional yaitu tahap penyidikan dan penuntutan, tahap adjudikasi dan tahap eksekusi pemenjaraan. ${ }^{34}$ Dalam perkembangannya, pertumbuhan dan penyebaran keadilan restoratif mendapat dukungan Perserikatan Bangsa-Bangsa (PBB). Dalam Kongres Lima Tahunan yang ke-5 di Jenewa tahun 1975, PBB mulai menaruh perhatian terhadap ganti rugi bagi korban kejahatan, sebagai alternatif bagi peradilan pidana retributif.

Konsep asli praktek keadilan restoratif berasal dari praktek pemeliharaan perdamaian yang digunakan suku bangsa Maori (penduduk asli suku di Selandia Baru). Bilamana timbul konflik, praktek restoratif akan

\footnotetext{
${ }^{32}$ Satjipto Rahardjo, Op. Cit., hlm. 30

${ }^{33}$ John Brithwaite, Restorative Justice and Responsive Regulation, (University Press, Oxford, 2002).

${ }^{34}$ Eriyantouw Wahid, Keadilan Restoratif dan Peradilan Konvensional dalam Hukum Pidana, (Jakarta: Universitas Trisakti, 2009), hlm. 1
} 
menangani pihak pelaku, korban, dan para stakeholders. ${ }^{35}$ Bahkan Jeff Christian, seorang pakar Lembaga Pemasyarakatan Internasional dari Kanada mengemukakan bahwa sesungguhnya peradilan restoratif telah dipraktekkan banyak masyarakat ribuan tahun yang lalu, jauh sebelum lahirnya hukum negara yang formalitas seperti sekarang yang kemudian disebut hukum modern. ${ }^{36}$

Pada dasarnya restorative justice mengutamakan makna pertemuan antar pihak berkepentingan dalam kejahatan dan periode sesudahnya. Seperti dikemukakan oleh Achmad Ali yang mengutip pendapat Howard Zher seorang perintis keadilan restoratif di Amerika Serikat, mengartikan restorative justice adalah "suatu proses yang melibatkan pihak-pihak yang berkepentingan dari sebuah pelanggaran khusus dan secara bersama-sama mengidentifikasi kerugian serta memenuhi kewajiban dan kebutuhan serta menempatkan perubahan sebagai hak yang harus diterima". ${ }^{37}$ Adrianus Meliala mengutip pendapat Morrison tentang restoratif adalah "is a form of conflict resolution and seeks to make it clear to offender that the behaviour id not condoned (welcomed), at the same time as being supportive resfectful of the individual". ${ }^{38}$ Berdasarkan pendapat tersebut, upaya penyelesaian konflik dan sekaligus penyembuhan antara pelaku dan korban caranya adalah dengan mempertemukan atau mengenalkan pelaku dalam satu forum dengan korban ataupun keluarganya untuk menumbuhkan empati di kedua belah pihak.

Dengan demikian, dalam penyelesaian konflik yang ditonjolkan bukan menegaskan kesalahan pelanggar kemudian menjatuhkan sanksi pidana, tetapi peran aktif pihak yang berkonflik melalui mediasi atau kompensasi terhadap kerugian materiil dan immateriil dalam bentuk restitusi atau kompensasi dan pemulihan keharmonisan hubungan kemanusiaan antar para pihak-pihak (humanisasi). Van Ness, seperti dikutip oleh Mudzakir, mengatakan bahwa keadilan restoratif (restorative justice) dicirikan dengan beberapa preposisi, yaitu:

a. kejahatan adalah konflik antar individu yang mengakibatkan kerugian pada korban, masyarakat, dan pelaku itu sendiri;

b. tujuan yang harus dicapai dari proses peradilan pidana adalah melakukan rekonsiliasi diantara pihak-pihak sambil saling memperbaiki kerugian yang ditimbulkan oleh kejahatan; dan

\footnotetext{
35 Hadi Supeno, Kriminalisasi Anak, Tawaran Gagasan Radikal Peradilan Anak Tanpa Pemidanaan, (Jakarta: Gramedia, 2010), hlm. 196

${ }^{36}$ Ibid.,

37 Achmad Ali, Menguak Teori Hukum (Legal Theory) dan Teori Peradilan (Judicial Prudence), (Jakarta: Kencana Prenada Media, 2009). Hlm. 247

${ }^{38}$ Adrianus Maliala, Restorative Justice dan Penegakan Hukum, Bahan Kuliah Mahasiswa PTIK Ang 54/55, Jakarta, 2009.
} 
c. proses peradilan pidana harus memfasilitasi partisipasi aktif para korban, pelanggar, dan masyarakat, tidak semestinya peradilan pidana didominasi oleh negara dengan mengesampingkan lainnya. ${ }^{39}$

Berdasarkan pendapat tersebut, seyogyanya sistem peradilan pidana dapat dilakukan dengan berbagai pendekatan-pendekatan yang tetap menegakan keadilan baik bagi korban maupun pelaku kejahatan. Secara teoritis terdapat tiga model yang menempatkan hubungan keadilan restoratif dengan sistem peradilan pidana, yaitu: ${ }^{40}$

a. sebagai bagian dari sistem peradilan pidana.

Adalah masuk akal jika keadilan restoratif sebagai suatu pemidanaan mengingat ciri dari pemidanaan adalah memaksa, menderitakan seiring dengan timbulnya rasa bersalah dan penyesalan dalam diri pelaku;

b. di luar sistem peradilan pidana melalui lembaga/institusi lain di luar sistem.

Pandangan keadilan restoratif berbanding terbalik dengan sistem peradilan pidana yaitu mengharamkan sifat keras dari hukum pidana atau disebut sebagai soft justice karenanya dia harus berada di luar sistem peradilan pidana; dan

c. di luar sistem peradilan pidana dengan tetap melibatkan pihak penegak hukum. Ini merupakan gambaran dari sistem kuasi di mana titik berat di sini adalah bahwa model penyelesaian dengan pendekatan restoratif tetap harus berdampingan dengan sistem peradilan pidana karena pada dasarnya model penyelesaian ini dapat dijadikan dasar dari strategi penanganan perkara pidana yang tujuannya diarahkan pada kebaikan pelaku, korban, dan masyarakat. Di samping itu hal ini juga menjadikannya sebagai bagian dari mekanisme yang sah dalam sistem hukum negara.

Berdasarkan beberapa pendapat di atas, jelas sudah bahwa keadilan restoratif adalah sebuah konsep pemikiran yang merespon pengembangan sistem peradilan pidana dengan menitikberatkan pada pelibatan masyarakat dan korban dalam penyelesaian perkara pidana yang ada. Pelibatan ini terkait dengan tahapan-tahapan penegakan hukum pidana di tingkat penyidikan, terutama dalam proses penegakan hukum kasus-kasus tertentu di Indonesia berdasarkan pada berat ringannya pidana yang dilakukan, besar kecilnya kerugian yang ditimbulkan, kondisi latar belakang dan motif pelaku, serta kondisi sosiologis masyarakat setempat. Lebih jauh lagi, apabila dilihat dari pengaturan tentang restorative justice secara internasional, jelaslah bahwa

39 Mudzakir, Viktimologi: Studi Kasus di Indonesia, makalah, pada Penataran Nasional Hukum Pidana dan Kriminologi ke XI, Tahun 2005, Surabaya.

${ }^{40}$ Eva Achjani Zulfa, Keadilan Restoratif di Indonesia (Studi tentang kemungkinan penerapan pendekatan keadilan restoratif dalam praktek penegakan hukum pidana), Disertasi, pada Universitas Indonesia, 2009, hlm. 180-183 
penggunaan restorative justice sebagai upaya penyelesaian perkara pidana, sudah diakui secara internasional. Konsep ini juga sesuai dengan hukum yang hidup dalam masyarakat Indonesia (hukum adat).

Di Indonesia sendiri, sebenarnya konsep restorative justice ini telah lama dipraktekkan dalam masyarakat Indonesia, seperti masyarakat di Papua, Bali, Toraja, Minangkabau, Kalimantan, Jawa Tengah, dan masyarakat komunitas lain yang masih kuat memegang kebudayaan. Apabila terjadi suatu tindak pidana oleh seseorang (termasuk perbuatan melawan hukum yang dilakukan oleh anak). Dalam prakteknya penyelesaiannya dilakukan dalam pertemuan atau musyawarah mufakat yang dihadiri oleh tokoh masyarakat, pelaku, korban (bila mau), dan orang tua pelaku untuk mencapai sebuah kesepakatan untuk memperbaiki kesalahan. Hal demikian sebenarnya merupakan nilai dan ciri dari falsafah bangsa Indonesia yang tercantum dalam sila keempat Pancasila, yaitu musyarawah mufakat. Dengan demikian, restorative justice sebetulnya bukan hal yang baru bagi masyarakat Indonesia. Dalam musyawarah mufakat bertujuan untuk mencapai kedamaian, sehingga antara pelaku dan korban tidak ada "dendam" dan korban dapat dipulihkan (direstor). Musyawarah mufakat dalam konteks restorative justice bisa dilakukan dengan cara, antara lain: mediasi, pembayaran ganti rugi, ataupun cara lain yang disepakati antara korban/keluarga korban dengan pelaku. Pihak lain bisa ikut serta dalam masalah ini, misalnya polisi, pengacara atau tokoh masyarakat sebagai penengah. Apabila penyelesaian ini tidak ada sepakat antara korban/keluarga korban dengan pelaku, maka selanjutnya penyelesaian masalah tersebut diproses secara mekanisme pengadilan yang ada (litigasi).

\section{Politik Hukum terhadap Konsep Restorative Justice dalam Pembaharuan Hukum Pidana yang akan Datang}

Pembaharuan hukum pidana materiil dalam bentuk Rancangan Undang-Undang Kitab Undang-undang Hukum Pidana (selanjutnya akan disingkat RUU KUHP), merupakan upaya mewujudkan cita negara hukum. Sehingga RUU KUHP merupakan manifestasi dari hal itu yang berkepribadian Indonesia, yang bukan hanya berpaham rule of law yang mengutamakan perlindungan kepentingan perseorangan (individualistis) model barat ataupun socialist legality yang mengutamakan kepentingan negara. Pembaharuan hukum bukan hanya memperbaiki hukum, tetapi mengganti hukum yang ada dengan hukum yang lebih baik. Sehingga RUU KUHP bukan sekedar mengadakan perubahan-perubahan seperlunya yang mengganti baju kolonial menjadi kemasan nasional, melainkan wujud dari kemerdekaan dan kedaulatan bangsa yang sesungguhnya. Bahkan pembaharuan hukum menentukan arah pembentukan watak bangsa, dari satu 
kondisi riil menuju pada kondisi ideal, sehingga RUU KUHP merupakan alat transformasi sosial dan budaya masyarakat secara terencana.

Hukum pidana sebagai salah satu bagian independen dari hukum publik merupakan salah satu instrumen hukum yang sangat urgent eksistensinya sejak zaman dahulu. Eksistensi hukum pidana sangat penting dalam menjamin keamanan masyarakat dari ancaman tindak pidana, menjaga stabilitas negara dan merupakan lembaga moral yang berperan merehabilitasi para pelaku tindak pidana. Sehingga hukum pidana terus berkembang sesuai dengan tuntutan perkembangan masyarakat. Salah satu perkembangan tersebut adalah munculnya ide penyelesaian konflik yang tidak hanya berfokus pada proses hukum di pengadilan, akan tetapi diselesaikan oleh para pihak yang berkonflik dengan cara memulihkan keadaan yang ada. Prinsip inilah kemudian dikenal dengan restorative justice yang diintrodusir dalam RUU KUHP melalui sejumlah ketentuan dalam Pasal 2, Pasal 12, Pasal 54, dan Pasal 55, adanya mediasi dalam Pasal 145 huruf d, serta diversi terhadap anak dalam sistem peradilan pidana anak. Munculnya konsep ini terutama untuk memberikan keseimbangan perhatian diantara stakeholders hukum pidana yaitu pelaku, korban, masyarakat, dan negara. Lebih lanjut, keseimbangan tersebut juga terlihat dalam hal pengaturan tentang pidana (straf/punishment) dengan pengaturan tentang tindakan (maatreegel/treatment /measures) dan dimungkinkannya sanksi gabungan antara pidana dan tindakan (double track system), mengingat heterogenitas masalah kejahatan, serta kesadaran tentang pentingnya terapi yang tepat terhadap victimless crime.

Sebenarnya konsep restorative justice merupakan wujud dari hukum adat yang sudah sejak dahulu berkembang dalam masyarakat Indonesia. Sehingga diakuinya hukum adat (the living law) dalam RUU KUHP bertujuan untuk memenuhi rasa keadilan yang hidup dalam masyarakat, dengan memulihkan keadaan yang telah rusak atau proses di mana pihakpihak berkepentingan memecahkan bersama cara mencapai kesepakatan pasca terjadi suatu tindak pidana termasuk implikasinya dikemudian hari. Dengan demikian, restorative justice dalam penanganan tindak pidana tidak hanya dilihat dari kacamata hukum semata, tetapi juga dikaitkan dengan aspek-aspek moral, sosial, ekonomi, agama, dan adat istiadat lokal serta berbagai pertimbangan lainnya.

Dalam proses acara pidana konvensional misalnya apabila telah terjadi perdamaian antara pelaku dan korban, dan sang korban telah memaafkan sang pelaku, maka hal tersebut tidak akan bisa mempengaruhi kewenangan penegak hukum untuk terus meneruskan perkara tersebut ke ranah pidana yang nantinya berujung pada pemidanaan sang pelaku. Proses formal pidana yang makan waktu lama serta tidak memberikan kepastian bagi pelaku maupun korban tentu tidak serta merta memenuhi maupun memulihkan 
hubungan antara korban dan pelaku, konsep restorative justice ini menawarkan proses pemulihan yang melibatkan pelaku dan korban secara langsung dalam penyelesaian masalahnya. Proses pidana konvensional hanya menjadikan korban nantinya sebagai saksi dalam tingkat persidangan yang tidak banyak mempengaruhi putusan pemidanaan, tugas penuntutan tetap diberikan terhadap Jaksa yang hanya menerima berkas-berkas penyidikan untuk selanjutnya diolah menjadi dasar tuntutan pemidanaan, tanpa mengetahui dan mengerti kondisi permasalahan tersebut secara riil, dan sang pelaku berada di kursi pesakitan siap untuk menerima pidana yang akan dijatuhkan kepadanya.

Selain itu, dalam perkembangan hukum pidana pada saat ini juga dikenal mediasi penal. Dalam praktek hukum pidana, mediasi penal dianggap sebagai sebuah turunan dari restorative justice, karena tidak perlu menjalankan hukum pidana melalui pengadilan. Meskipun penyelesaian perkara di luar pengadilan (Alternative Dispute Resolution/ADR) umum atau lazimnya diterapkan dalam perkara perdata, tetapi tidak untuk perkara pidana. Sebab pada tataran asas, perkara pidana tidak dapat diselesaikan di luar pengadilan, tetapi dalam prakteknya untuk hal-hal tertentu mungkin terjadi, bahkan boleh jadi penyelesaian di luar pengadilan menjadi hal yang ideal.

Dalam perkembangan wacana teoritik maupun perkembangan pembaharuan hukum pidana di berbagai negara ada kecenderungan kuat untuk menggunakan mediasi penal sebagai salah satu alternatif penyelesaian masalah di bidang hukum pidana. Tidak bisa dipungkiri lagi, bahwa praktek penegakan hukum di Indonesia yang dalam perkara pidana diselesaikan di luar pengadilan melalui diskresi aparat penegak hukum, belum lagi dalam praktek masyarakat juga melakukan bentuk-bentuk diskresi atas perkara pidana (social discretion) melalui mekanisme perdamaian, penyelesaian lembaga adat, dan lain sebagainya, yang kemudian menyebabkan tuntutan untuk mempositifkan bentuk-bentuk penyelesaian perkara di luar pengadilan semakin menguat.

Sebagaimana telah dikemukakan sebelumnya, pada dasarnya restorative justice mengembalikan konflik kepada pihak-pihak yang paling terkenal untuk mempengaruhi korban, pelaku dan kepentingan komunitas mereka dan memberikan keutamaan pada kepentingan-kepentingan mereka. Restorative justice juga menekan pada hak asasi manusia dan kebutuhan untuk mengembalikan dampak dari ketidakadilan sosial dan dalam cara-cara yang sederhana memberikan pelaku keadilan daripada keadilan formal (hukum) korban tidak mendapatkan keadilan apapun. Kemudian restorative justice juga mengupayakan untuk me-restore keamanan korban, 
penghormatan pribadi, martabat dan yang lebih penting adalah sense of control. ${ }^{41}$

\section{Penutup \\ 1. Kesimpulan}

Sebagai bagian akhir dari tulisan ini, dapat disimpulkan bahwa politik hukum pembaharuan hukum pidana di Indonesia saat ini masih terus berlangsung dan menjadi bagian dari pembangunan sistem hukum nasional. Politik hukum pembangunan sistem hukum nasional harus berdasarkan Pancasila sebagai pemandu dan alat filterisasi bagi politik hukum nasional dan UUD NRI Tahun 1945 sebagai hukum dasar. Salah satu bentuk politik pembaharuan hukum pidana dikenal adanya konsep restorative justice yang menjadi alternatif mekanisme penyelesaian masalah hukum yang terjadi tanpa menggunakan proses peradilan.

Dengan pendekatan restorative justice ini, penegakan hukum dari yang selama ini selalu menggunakan pendekatan retributif (pembalasan) semata-mata akan bergeser menjadi pendekatan restoratif (pemulihan). Konsep restorative justice dapat menjadi politik hukum yang bersifat tetap (permanen) dalam membangun sistem hukum pidana nasional yang akan datang.

Dengan pendekatan restoratif ini, penyelesaian perkara pidana lebih mengutamakan hal-hal sebagai berikut:

a. dalam penyelesaian perkara pidana di Indonesia selama ini sebenarnya dapat dilakukan dengan menggunakan pendekatan restorative justice, di mana mekanisme yang digunakan dengan cara musyawarah mufakat antara pelaku, korban/keluarga korban, masyarakat, dan negara sebagai stakeholders dari hukum pidana;

b. bahwa sebenarnya mekanisme penyelesaian perkara pidana dengan pendekatan restorative justice sudah lama diterapkan oleh masyarakat Indonesia. Bahkan berkembang dan eksis dalam kehidupan masyarakat, karena secara in concrito dapat membawa kemanfaatan bersama dan menghindari dampak buruk pidana penjara serta pemulihan bagi korban akan hak-haknya. Hanya saja belum secara formal menjadi bagian dari sistem hukum (legal system) Indonesia;

c. dalam konteks pembaharuan hukum pidana di Indonesia juga telah mengakomodir prinsip restorative justice sebagaimana diatur dalam RUU KUHP nasional, di mana rumusan tentang jenis-jenis pidana (strafmaat) mengandung sifat restoratif. Begitu juga halnya dalam undang-undang sistem peradilan pidana anak. Sehingga sangat mungkin sekali konsep

41 BPHN, Perencanaan Pembinaan Hukum Nasional Bidang Politik Hukum Pidana dan Sistem Pemidanaan, 2012 
restorative justice ini dapat dijadikan bagian dari pembaharuan hukum pidana di Indonesia di masa yang akan datang.

\section{Saran}

Guna mencapai maksud yang terdapat dalam simpulan tersebut, maka disarankan :

a. bagi penegak hukum ke depannya juga harus merubah paradigma berpikirnya dalam penyelesaian perkara pidana agar tidak selalu menggunakan pendekatan retributif yang mengutamakan pidana penjara atau bentuk pidana lainnya yang kadang-kadang justru bertentangan dengan tujuan hukum pidana itu sendiri;

b. bagi pembentuk undang-undang ke depannya perlu memikirkan secara serius, serta memfasilitasi untuk menjadikan pendekatan restorative justice ini sebagai bagian dari sistem hukum nasional, sehingga menjadi bagian dari mekanisme penyelesaian perkara dalam sistem peradilan pidana indonesia; dan

c. perlu adanya upaya yang serius dari pemerintah untuk segera mungkin menyelesaikan proses pembahasan, pengesahan, dan pemberlakuan KUHP nasional yang baru yang sesuai dengan nilai-nilai ke-Indonesiaan. Mengingat KUHP yang berlaku sekarang sudah tidak cocok lagi dengan budaya bangsa Indonesia yang berdasarkan pada hukum adat, hukum Islam, serta nilai-nilai kebhinekaan lainnya. 


\section{Daftar Pustaka}

\section{A. Buku}

Ali, Achmad, 2009. Menguak Teori Hukum (Legal Theory) dan Teori Peradilan (Judicial Prudence), Jakarta: Kencana Prenada Media.

Atmasasmita, Romli, 2012, Teori Hukum Integratif: Rekonstruksi Terhadap Teori Hukum Pembangunan dan Teori Hukum Progresif, Yogyakarta: Genta Publishing.

Brithwaite, John, 2002. Restorative Justice and Responsive Regulation, Oxford: University Press.

Fuady, Munir, 2003. Aliran Hukum Kritis, Paradigma Ketidakberdayaan Hukum, Bandung: Citra Aditya Bakti.

Hartono, Sunaryati, 1986. Perspektif Politik Hukum Nasional, Dalam Artidjo Alkostar dan M, Sholeh Amin (Ed), Pembangunan Hukum Dalam Perspektif Politik Hukum Nasional, Jakarta: Rajawali. , 1991. Politik Hukum Nasional Menuju Satu Sistem Hukum Nasional, Bandung: Alumni. , Hukum Ekonomi Pembangunan Indonesia, Bandung: Bina Cipta.

Hoefnagels, G.P., 1978. The Other side of Criminology, Holland: DeventerKluwer.

Lev, Daniel S., 1990. Hukum dan Politik di Indonesia: Keseimbangan dan Perubahan, Cetakan I, Jakarta: LP3ES.

MD, Moh. Mahfud, 1998. Politik Hukum di Indonesia, Jakarta: Pustaka LP3ES Indonesia.

Manan, Abdul, 2009. Aspek-Aspek Pengubah Hukum, Jakarta: Kencana Prenada Media.

Manan, Bagir, 1996. Politik Hukum Otonomi Sepanjang Peraturan Perundang-undangan Pemerintahan Daerah, Dalam Martin H, Hutabarat, et, al (Penyunting), Hukum dan Politik Indonesia: Tinjauan Analitis Dekrit Presiden dan Otonomi Daerah, Jakarta: Sinar Harapan.

Nawawi, Barda Arief, 1996. Bunga Rampai Kebijakan Hukum Pidana, Bandung: Citra Aditya Bakti.

Radhie, Teuku Muhammad, 1980. Beberapa Pemikiran Pembangunan Hukum di Indonesia, Bandung: Alumni.

Rahardjo, Satjipto, 1993. Masalah Penegakan Hukum Suatu Tinjauan Sosiologis, Jakarta: Badan Pembinaan Hukum Nasional Departemen Kehakiman.

Rosadi, Otong dan Andi Desmon, 2013. Studi Politik Hukum: Suatu Optik Ilmu Hukum, Edisi II, Yogyakarta: Thafa media. 
Sofyan, Syofrin dan Asyhar Hidayat, 2003. Hukum Pajak dan Permasalahannya, Bandung: Refika Aditama.

Sudarto, 1981. Hukum dan Hukum Pidana, Bandung: Alumni. , 1983. Hukum Pidana dan Perkembangan Masyarakat, Bandung: Sinar Baru.

Supeno, Hadi, 2010. Kriminalisasi Anak, Tawaran Gagasan Radikal Peradilan Anak Tanpa Pemidanaan, Jakarta: Gramedia.

Wahid, Eriyantouw, 2009. Keadilan Restoratif dan Peradilan Konvensional dalam Hukum Pidana, Jakarta: Universitas Trisakti.

Wahyono, Padmo, 1986. Indonesia Negara Berdasarkan Atas Hukum, Jakarta: Ghalia Indonesia.

Waluyo, Bambang, 2011. Viktimologi Perlindungan Saksi dan Korban, Jakarta: Sinar Grafika.

Zulfa, Eva Achjani, 2009. Keadilan Restoratif di Indonesia (Studi tentang kemungkinan penerapan pendekatan keadilan restoratif dalam praktek penegakan hukum pidana), Disertasi, pada Universitas Indonesia.

\section{B. Lain-lain}

BPHN. 2012. Perencanaan Pembinaan Hukum Nasional Bidang Politik Hukum Pidana dan Sistem Pemidanaan.

Hakim Garuda Nusantara, Abdul. "Politik Hukum Nasional”, makalah disampaikan pada Karya Latihan Bantuan Hukum (Kalabahu), diselenggarakan Yayasan LBH Indonesia dan LBH Surabaya, September 1985.

Hartono, Rudi. Kewenangan Kepolisian Menurut KUHAP Dalam Perspektif HAM, makalah Semiloka: KUHAP dan Menuju Fair Trial "Victim Protection”. LBH Yogyakarta, 24 Juli 2013.

Huda, Chairul. "Politik Hukum Pembangunan Sistem Hukum Nasional Dalam Konteks Pancasila, UUD NRI Tahun 1945, dan Global", Malakah disampaikan pada Seminar Nasional Fakultas Hukum Universitas Muhammadiyah Jakarta, Tanggal 22 November 2014

Mahfud MD, Politik Hukum Menuju Pembangunan Sistem Hukum Nasional, Seminar Arah Pembangunan Hukum Menurut UUD 1945 Hasil Amandemen, BPHN, 2006. Dalam konteks ini politik hukum diartikan sebagai arah yang harus ditempuh dalam pembuatan dan penegakan hukum guna mencapai cita-cita dan tujuan negara.

Maliala, Adrianus. Restorative Justice dan Penegakan Hukum, Bahan Kuliah Mahasiswa PTIK Ang 54/55, Jakarta, 2009.

Mudzakir, Viktimologi: Studi Kasus di Indonesia, makalah, pada Penataran Nasional Hukum Pidana dan Kriminologi ke XI, Tahun 2005, Surabaya. 